\title{
A Reply to Žižek: Reading Fundamentalism (or ISIS) Using Correct Cultural References
}

\author{
Burcu Kaya Erdem
}

Ph.D.,.Assoc. Prof., Istanbul University Communication Faculty, Istanbul, Turkey

Email: burcu.erdem@istanbul.edu.tr

Remzi Bilge

Research Assist., Istanbul University Communication Faculty, Istanbul, Turkey

Email: remzi.bilge@istanbul.edu.tr

Doi:10.5901/mjss.2015.v6n3p786

\section{Abstract}

In his article "ISIS is a Disgrace to True Fundamentalism," in which Žižek examines what triggers the violent reactions of Islam, he questions whether the terrorist fundamentalists are really fundamentalists or not. This paper is written with the justification that there is a very fundamental problem in terms of communication science in Žižek's evaluations of the communicative and operational attitudes of ISIS, evaluations that can be taken as a reference. Using the method of hermeneutic reading, this paper will discuss the comments Žižek makes without taking into consideration the local reference values of ISIS's fundamentalism which find their roots in the Islamic literature, starting with these questions: Can a person, or a point of view, that had been born and raised in a culture, read correctly another who is completely foreign to himself as a subject of an understanding that has evolved in its own conditions? Does not the state of failing to read correctly leads one face to face with the danger of falling into the trap of orientalism? This discussion will reveal that the greatest mistake one can do while dealing with Salafi terrorist groups that originated in the Middle East is to evaluate them within the same circle together with Buddhist and Christian fundamentalists as well as with other Muslims because the reference values and the vision of paradise of Salafi Islam do not resemble those of other religions. Contrary to Žižek's arguments, what makes a Salafi living in the Middle East anti-American is not his fight against his "own temptation" but his ambition of turning the world, of those who have established his own paradise that he wants to enter - and the American Dream - on earth, into hell. The American Dream that is being propagated through media has a role in the construction of this ambition as much as Salafi references. Finally, this paper proposes a way against the prophecy that "the children of Mount Olympus and of Mount Hira will never understand each other" (Meriç, 2013) and exemplifies this way through a hermeneutic reading of ISIS: of fulfilling one's intellectual responsibility through providing readings that do not exclude the will to know local cultural values...

Keywords: Žižek; ISIS; fundamentalism; Islam; Orientalism.

\section{Introduction}

Žižek's article "ISIS is a Disgrace to True Fundamentalism", published in the New York Times on 3 September 2014, received a wide coverage in almost all media and has been criticized in the academia in Turkey with its quality of reinforcing the view that the world history is indispensably and structurally divided into East and West. The controversial parts of this article was in fact published previously on the Lacan.com website and in his article titled "The Antinomies of Tolerant Reason: A Blood-Dimmed Tide is Loosed", which was published in a book printed in Turkish (İslam ArşivleriArchives of Islam).

This paper aims to provide a hermeneutic reading of Žižek's article under the light of correct references and values. Hence, the paper here offers a re-reading of the relevant portions of the mentioned article of the thinker, as well of his other works that provide the same narrative, with correct cultural references that are intrinsic to the Islamic literature.

The starting point of this paper is that Žižek fails to read correctly the fundamentalist character - and hence the communicative actions and discourses - of the "bad people" he mentions when he writes in his article "the best lack all conviction, while the worst are full of passionate intensity" since he reads from a point of view that has different cultural values, and therefore this inadequate reading makes the traps of orientalism inevitable.

The most important fallacy is the following: Just as we cannot speak of a monolithic West or a Christianity, we cannot similarly speak of a monolithic East or a perception of Islam. In this context, in a study that deals with radical Islamic organizations such as ISIS, it becomes necessary to examine the Salafi approach with its theological foundations 
instead of targeting Islam monolithically with its mechanisms of perception and practices. It's best if we quote Žižek's words from his relevant articles and explain their problematic aspects through uncovering them.

Before moving on to radical fundamentalist, it is crucial that we begin with the general problem of evaluation that emerges in the works of Žižek. According to Žižek (2014:8):

This is what those who see globalization as the chance for the entire earth as a unified space of communication, bringing together all humanity, fail to notice: since a Neighbor is (as Freud suspected long ago) primarily a Thing, a traumatic intruder, someone whose different way of life (or, rather, way of jouissance materialized in its social practices and rituals) disturb us, throw off the rails the balance of our way of life, when the Neighbor comes too close, this can also give rise to aggressive reaction aimed at getting rid of this disturbing intruder - or, as Peter Sloterdijk put it: "More communication means at first above all more conflict." This is why he was right to claim that the attitude of "understanding-each-other" has to be supplemented by the attitude of "getting-out-of-each-other's-way," by maintaining an appropriate distance, by a new "code of discretion." European civilization finds it easier to tolerate different ways of life precise on account of what its critics usually denounce as its weakness and failure, namely the "alienation" of social life. ... Sometimes, alienation is not a problem but a solution.

This assessment is the source of the views of the author that are problematic for two reasons, and this is what motivated the writing of this paper. Firstly, it should not be forgotten that the capability of the European civilization to easily tolerate dissimilar ways of life, that is to say, the case of alienation in social life is open to discussion. Indeed, the hegemony that is created by the action of the West who claims to bring democracy to the East, and the destruction that is the result of this hegemony, does not make a reference to tolerating dissimilar ways of life. If it did, there would not be a need for "a mission of the West to bring democracy to this region" even though the East has developed its particular democratic models and its own particular worldview. Secondly, alienation is not just an "internal thing" through which we put a material distance between us. Alienation can be both an internal and external structure that can metamorphose for any reason. In this very aspect, alienation is exactly othering. The alienation of the Western civilization toward the East has never consisted of ignoring or keeping out of its way throughout its history. What this alienation creates is far from being positive, constructive or supportive, rather, it is a relation of othering that is established with an attitude that has the tendency of rejecting and destroying. As expressed by Spinoza when he said "Omnis determinatio est negatio", that is, "every determination is a negation" (Spinoza, 1922, Epist. 59), every determination one makes about oneself is also a negation about a "non-self". The alienation of the West from its eternal other, the East, is an othering attitude that suggests a refusal of the other, much more than getting out of the other's way out of tolerance. In summary, it has not been easy to dose the degree of alienation. If we take the words of Peter Sloterdijk which Žižek quotes: "More communication means at first above all more conflict", and less communication does not mean less conflict. On the contrary, "less communication with the East" is the basic foundation of the mechanism that creates orientalism by excluding the will to know the other as is. The key to less conflict is communication that is established with a will to understand the values of local references, rather than with "universal" - that is, Western - values which study what pertains to the East only at the imagery level. (Zizek, 2015)

Unfortunately, as Edward Said said:

\begin{abstract}
...it's true that no production of knowledge in the human sciences can ever ignore or disclaim its author's involvement as a human subject in his own circumstances, then it must also be true that for a European or American studying the Orient there can be no disclaiming the main circumstances of his actuality: that he comes up against the Orient as a European or American first, as an individual second... It meant and means being aware, however dimly, that one belongs to a power with definite interests in the Orient, and more important, that one belongs to a part of the earth with a definite history of involvement in the almost since the time of Homer. (Said 2003:11)
\end{abstract}

Surely for it would be unfair to suggest that the narratives of Žižek, and of many Western thinkers, on the East is defined by the prevalent political concerns that creates orientalism. Actually Žižek is reading the East in its cultural role, and in the context of its logic of ideology, politics and power, as one should be doing. Yet, it is also within the responsibility of the intellectual to have an opinion after having acquired enough information about the local references.

\title{
2. Methodology: Hermeneutic Reading
}

In its most simple definition, hermeneutics is a tradition of thinking or philosophical thinking that tries to bring clarity to the concept of understanding.

As well known, hermeneutics studies a text according to the conditions and environment in which the text was 
written, its grammatical composition and unity, or according to its worldview. Hermeneutics serves for unfolding the text in terms of its messages; the text whose author delivered through various tools of communication but whose reader has a difficulty of comprehending for various reasons. (Özcan, 2000: 253)

The word has an affinity with meaning within the period and context in which it was used. As time and context changes, the word and meaning move apart from each other. The effort of hermeneutics is to bring the word and meaning, which are moving away from each other as a natural result of time and context, close to each other. This effort is as such even though it may at times be to the detriment of the word, and even an expression of its exact opposite. (Gürhan, 2011: 116).

The reason why this method is chosen for this paper is the hermeneutic approach of Gadamer that begins from the concept of "prejudice". According to Gadamer, "actually prejudice means a judgment that is rendered before all the elements that determine a situation have been finally examined" (Gadamer, 2013: 283).

Gadamer states that as far as we adopt a critical attitude and avoid unjustified prejudices, we arrive at new significations, new and reliable information at the end of our interpretive action. Yet, Gadamer does not provide an explication on how to make a distinction on the legitimacy of prejudices - between unjustified and legitimate prejudices. According to him, as long as we can avoid unjustified prejudices, we reach a historical consciousness through the knowledge we attain at the end of an investigative and critical process. (Çelik, 2013: 127-144, 132)

This is what is aimed in this study: reaching new meanings, new and reliable knowledge through avoiding unjustified prejudices and even through deciphering those of others in an investigative and critical way. In this context, this paper will attempt to provide a new meaning to the unjustified prejudices on Islamic fundamentalism in Žižek's text, by way of legitimate cultural references that originates in Islamic literature. The aim is to attain a cultural consciousness that has a command on local references through the information we arrive at the end of an investigative and critical process.

\title{
3. Žižek's Fallacy...
}

Žižek begins his article "ISIS is a Disgrace to True Fundamentalism" by stripping ISIS off its true fundamentalist guise with these arguments: Religious rules are more supportive rules than essential rules in the line of action of ISIS militants, and that ISIS isn't a case of extreme resistance to modernization, one should rather conceive of it as a case of perverted modernization. Žižek says:

\begin{abstract}
It may appear that the split between the permissive First World and the fundamentalist reaction to it runs more and more along the lines of the opposition between leading a long satisfying life full of material and cultural wealth and dedicating one's life to some transcendent cause. Is this antagonism not the one between what Nietzsche called "passive" and "active" nihilism? We in the West are the Nietzschean Last Men, immersed in stupid daily pleasures, while the Muslim radicals are ready to risk everything, engaged in the struggle up to their self-destruction. William Butler Yeats' "Second Coming" seems perfectly to render our present predicament: "The best lack all conviction, while the worst are full of passionate intensity." This is an excellent description of the current split between anemic liberals and impassioned fundamentalists. "The best" are no longer able fully to engage, while "the worst" engage in racist, religious, sexist fanaticism. (Zizek, 2014a)
\end{abstract}

Here, the notion of "impassioned" expresses the "disgraceful" passionlessness of ISIS even though it portrays ISIS in a passionate light.

The same attitude is also observed in another article of Žižek on the publication of caricatures depicting Prophet Muhammad in Denmark against the tradition of aniconism, in which he used the notion of "true egoist" in place of "true fundamentalist":

A true egotist is all too busy with taking care of his own good to have time to cause misfortunes to others; a violent pseudo-fundamentalist is, on the contrary, more occupied with (causing misfortune to the) others than with (providing a happy life to) himself. And does this not hold for fundamentalist violence, be it the Oklahoma bombings or the attack on Twin Towers? In both cases, we were dealing with hatred simple and pure: destroying the obstacle (Oklahoma City Federal Building, Twin Towers) was what really mattered, not achieving the noble goal of a truly Christian or Muslim society. (Zizek, 2014b: 10)

And Žižek deepens the mentioned assessment and raises his criticism by comparing Islamic fundamentalism with Tibetan Buddhists and Amish whom he describes as "authentic fundamentalists": 
But are the terrorist fundamentalists really fundamentalists in the authentic sense of the term? Do they really believe? What they lack is a feature that is easy to discern in all authentic fundamentalists, from Tibetan Buddhists to the Amish in the United States - the absence of resentment and envy, the deep indifference towards the nonbelievers' way of life. If today's so-called fundamentalists really believe they have found their way to Truth, why should they feel threatened by nonbelievers. Why should they envy them? When a Buddhist encounters a Western hedonist, he hardly condemns. He just benevolently notes that the hedonist's search for happiness is self-defeating. In contrast to true fundamentalists, the terrorist pseudo-fundamentalists are deeply bothered, intrigued and fascinated by the sinful life of the nonbelievers. One can feel that, in fighting the sinful other, they are fighting their own temptation. This is why the so-called fundamentalists of ISIS are a disgrace to true fundamentalism. (Zizek, 2014a)

The answer to the question "Do they really believe?" that Žižek poses can be provided more realistically with references pertaining to Islam. Because it is surely impossible to explain this strain of radicalism by comparing Salafi currents such as ISIS with Buddhists and Christian fundamentalists.

The last step in Žižek's determinations is the state of "considering oneself inferior" that is shown to be the source of the violent orientations of the organization against the West:

The problem with terrorist fundamentalists is not that we consider them inferior to us, but, rather, that they themselves secretly consider themselves inferior. This is why our condescending, politically correct assurances that we feel no superiority toward them only makes them more furious and feeds their resentment. (Zizek, 2014a)

In another article, Žižek criticizes the inferiority complex of Muslims with these words:

"Let us see how tolerant YOU are!" in no way changes this fact. In short, this reaction is a proof that what really matters to the enraged Muslims is a struggle for recognition and respect, a sense of humiliation and hurt pride, NOT religion. (Zizek, 2014a: 12)

All these determinations unfortunately remind us of the orientalists' views on Arabs which Edward Said exemplified in his work Orientalism:

... we are told that Arabs stress conformity; that Arabs inhabit a shame culture whose "prestige system" involves the ability to attract followers and clients; that Arabs can function only in conflict situation; that prestige is based on solely on the ability to dominate others; that a shame culture... (Said, 2003: 48)

\section{Reading ISIS Using Correct Cultural References}

We need to investigate the theological grounds of ISIS and most of the other radical Islamist organizations that have become a current issue with their bloody actions in the Middle East today in order to be able to analyze them. These organizations belong to the Salafi doctrine of Islam. This sect, whose name comes from the Arabic word "salaf" which means "predecessors" (Sönmez, 2010:172), is grounded on being dependent on the interpretations and practices of those whom they consider as their predecessors, without making any changes and without questioning them. Those who are considered as legitimate predecessors are called "Salaf us-Salih" and consists of the Prophet; the companions of the Prophet (Sabaha); those who had not seen the Prophet but his companions (Tabi'un); and, those who were born after the passing of companions but were the contemporaries of Tabi'un (Tabi' al-Tabi'in). In their faith and lives, these people are considered to be distant to innovations, that is, practices that were invented afterwards and were not actually part of religion, and are considered to be feeding from directly from the source. The following words of the Prophet of Islam, Muhammad, "The companions of my own generation are the best, then those who come after them (Tabi'un), and then those of the next generation (Tabi' al-Tabi'in)," (Tirmizî, Fiten, 45: 2221) pointing at these predecessors resulted in the faith about the reliability of these people in passing on Islam to next generations correctly in the Salafi creed.

\subsection{ISIS's Theological Foundations: The Salafi Approach}

Salafi creed is not a sectarian division but rather expresses a method, an approach (Yllmaz, 2014: 539) and the difference of this approach is basically about the use of the intellect in textual exegesis. A Salafi disdains the intellect to the degree that s/he sanctifies the first generations and the transmission in accordance to the essence of his/her creed (Sönmez, 2010, 182). Because according to this understanding, no source can supersede the narratives of those people who are recognized as the "best of all people" by the messenger of God. According to the Salafi acceptances, intellectual 
methods are methods that were invented afterwards, and were not known by the Salaf us-Salih (Sönmez, 2010, 182). As a result of the hadith "The best talk (speech) is Allah's Book 'Qur'an), and the best way is the way of Muhammad, and the worst matters are the heresies (those new things which are introduced into the religion); and whatever you have been promised will surely come to pass, and you cannot escape (it)." (Bukhari, l'tisam, 2:7277), Salafis consider all methods based on rationality, including interpretation, as innovation, and fiercely object to any commentary on the verses of the Quran because there are nobody more potent than Salaf us-Salih with regard to the true path. Whatever the predecessors had understood of Islam, that is the meaning of Islam which cannot be interpreted otherwise. Any other "methods such as opinion, comparison, interpretation, commentary, consensus, or inspiration do not pertain to religion" (Sönmez, 2010, 184).

For a Salafi, it is not an appropriate attitude for a believer to ask questions on issues about faith, to go into particulars, to make them a subject that requires rational explanation or comparison. Salafis have not been interested in asking questions or digging into the meaning of the verses since they have deemed these actions as tools of introducing seeds of doubt into faith, and they have attempted to give prominence to religious practice ${ }^{1}$. Practice coming into prominence on the subject of faith has led to an exoteric understanding of Islam in Salafiyyah. In this way, all the areas of life began to be assessable within religion and a complete unity of religion and social life, politics and law was asserted (İşcan, 2013:165). As a result of this understanding, Takfiri Salafiyyah emerged; the word takfiri is derived from the word takfir, which means ruling sacrilege ${ }^{2}$ After this point, for some radicals of the Salafiyyah, this paved the way to excommunicating anyone who does not think like them.

Another important aspect that distinguishes Salafiyyah is that the creed sees itself as a movement of reviving religion. The aim of this reviving movement is not to interpret what is contemporary, but rather "to return to the purity during the time of the Prophet, Sahabah, and Tabi'un, that is called Era of Bliss, or Golden Age" (Yılmaz, 2014:540). In other words, the Salafi theology calls its followers to a rapid revolution and mobility movement that concerns the whole Muslim community rather than to a contemporary individual salvation plan, and makes its followers a part of a sacred mission that is timeless. The high motivation that is sustained by the extraordinary situation that is generated by the mission of reviving religion, refining it to its previous purity, maintains itself due to the foundations of the faith, and can thus easily turn the believer into an object of radicalism.

The answer of one of the perpetrators who participated in a bombing in Istanbul to the question "What is Salafi creed?" should be sufficient for those who wonder how this mission is embraced by the Salafiyyah: "Salaf means those who came first. These people take the example of the lives at the times of Sabaha, Tabi'un, Tabi' al-Tabi'in and people of the good deeds. Salafi means those who are subject to these examples. I take these great people as an example and try to live by the Salafi creed as much as I can. I believe that today, the faith that is known as the People of the Sunnah has lost its purity. It contains elements of kalam [dialectics] and innovations" (Işcan, 2013: 161-162). In conclusion, for a Salafi who believes in the timeless mission designated to him by theology and acts upon the principle "If Allah says so, it is so" (Sönmez, 2010:184), nothing is open to debate or interpretation, including the verses of Quran that commends jihad.

\subsection{The Topic of Jihad in the Literature of Quran-Hadith and the Salafiyyah Understanding of Jihad}

After understanding how Salafiyyah deals with Quran and Hadith, we can attempt to understand how these sources of reports handle the subject of jihad from the point of view of a Salafi. The word jihad in Arabic is a word derived from the root jahd which means endeavoring, struggling. In its particular meaning jihad means the struggle of a Muslim on the path of Allah. There is this struggle is because according to Islamic faith, the world is divided into two: Dar al-Islam [house/abode of Islam] and Dar al-Harb [house of war]. According to the Islamic faith, Dar al-Islam are those places "under the rule of Muslims where Muslims fulfill their religious duties, living in safety and security" whereas Dar al-Harb are places "under the rule of non-Muslims with those whom Muslims do not have a covenant or a reconciliation" (Bilmen, 1999: 394).

The mission of fighting against disbelievers in order to glorify the name of Allah, which is referred to as "i'lay-I Kalimetullah" is a fardh, that is, a religious duty commanded by Allah, mentioned in many verses of Quran and is handled with various differences of interpretation by Muslims. According to the verses of Quran, the reason why there is jihad is because there are people who refuse the invitation of Islam (kafir). For instance, 123' ayah (verse) of the $9^{\text {th }}$ sura says: "You who believe, fight the disbelievers near you and let them find you standing firm: be aware that God is with those who

\footnotetext{
${ }^{1}$ Deeds that are performed in order to follow religious orders.

${ }^{2}$ The practice of excommunication, one Muslim declaring a non-Muslim or an apostate, an unbeliever or kafir. 
are mindful of Him." ${ }^{13}$ and invites Muslims to fight disbelievers. Jews and Christians are distinguished from polytheists and disbelievers, and the command to jihad is revoked in case they pay the jizya tax that is the double of the religious tax called zakat, which Muslims are supposed to pay: "Fight those of the People of the Book who do not [truly] believe in God and the Last Day, who do not forbid what God and His Messenger have forbidden, who do not obey the rule of justice, until they pay the tax [izzya] promptly and agree to submit." (Quran 9: 29).

There are controversies about the verses of Quran that evoke jihad among the Muslims today, such as this one: "Fighting has been ordained for you, though it is hard for you. You may dislike something although it is good for you, or like something although it is bad for you: God knows and you do not." (Quran 2: 216). Especially modern commentators suggest that the verses of Quran about jihad should be evaluated together with the political circumstances in which the Quran was revealed, and should be read as a struggle to keep Islam triumphant through an intellectual struggle today rather than a call to fight against those who are different. Doubtless this view suggests the reinterpretation of what is transmitted according to the current times through a rational argumentation even though this fierce debate whose accuracy or falseness does not concern our study here. Thus, this interpretation is an outcome which a Salafi would not I does not arrive at after reading the relevant verses of Quran.

When a Salafi reads the words in the $111^{\text {th }}$ verse of $9^{\text {th }}$ sura "God has purchased the persons and possessions of the believers in return for the Garden - they fight in God's way: they kill and are killed - this is a true promise given by Him in the Torah, the Gospel, and the Qur'an" s/he will want to look at how Salaf us-Salih had practiced this verse rather than tending toward "pen instead of sword" inference which suggests that "the mentioned mode of struggle was a result of those conditions that were present centuries ago and hence different methods should be implemented today". For a Salafi, who chooses to resolve the problem of the source by turning to predecessors, the hadith "Surely, the gates of Paradise are under the shadows of the swords." (Muslim, Imara, 41: 1902) will be enough to struggle through the means of fighting.

A Salafi who reads the hadith "I have been ordered (by Allah) to fight against the people until they testify that none has the right to be worshiped but Allah and that Muhammad is Allah's Apostle, and offer the prayers perfectly and give the obligatory charity, so if they perform that, then they save their lives and property from me except for Islamic laws and then their reckoning (accounts) will be done by Allah." (Bukhari, Iman, 17: 25) will not interpret the hadiths based on the idea that real jihad may be realized without fighting (such as Tirmidhi Jihad, 2: 1671) and will not question the possibility that jihad might mean something other than war. The only thing left for a radical believer who somehow finds himself/herself in an organization with a Salafiyyah motive will long for reaching the promise transmitted by the hadith "Paradise has one-hundred grades which Allah has reserved for the Mujahidin who fight in His Cause, and the distance between each of two grades is like the distance between the Heaven and the Earth." (Bukhari, Jihaad, 4: 2790), since opting for interpretation through rational reasoning blunts his/her categories. On the other hand, any Muslim who can use transmitted resources and intellectual resources in a balanced way can interpret the related verses in our current day toward gaining scholarly superiority without denying the essence of these two sources, and can in this way find nonviolent ways of struggling with the "other" without coming to an absolute conclusion of war.

\subsection{Discussing Two Ideals As the Root Causes of Struggle: The Paradise of the Radical and The American Dream}

Even though there is a debate among Muslims about what the verses on jihad state, there is a clear vision about the image of paradise which the Quran creates in almost all believers' minds. In the Islamic eschatology, a deceased person remains in the grave until the judgment day. Following the resurrection of all humanity, a judgment is made and people are sent to either hell or paradise. The paradise image mentioned in Quran is very visual. A person's relation to paradise is mainly established through gratifying the sense of vision: "if you looked around you would see bliss and great opulence" (Quran 76:20).

Muslims believe that those who go to paradise will be rewarded with provision that will never end (Quran 38:54), gardens of lasting bliss graced with flowing streams (Quran 20:76), lofty dwellings (Quran 34:37), will be adorned with golden bracelets and pearls, will have silken garments (Quran 22:23), with them will be spouses - modest of gaze and beautiful of eye - (Quran 37:48), dark-eyed [maidens], sheltered in pavilions (Quran 55:72), beautiful-eyed maidens (Quran 56:22), virginal, loving, of matching age (Quran 56:36,37). What is crucial for Muslims about paradise is to be faithful, doing good deeds, or to die a martyr with faith.

From the point of view of a Salafi, becoming a martyr in order to be worthy of paradise, and the paradise vision for

${ }^{3}$ The Quran, translated by M.A.S. Abdel Haleem, Oxford University Press, 2010. All English translations of Quran are taken from this work. 
martyrdom is very motivating because as transmitted in the hadith, those who pursue jihad will be rewarded differently from other regular Muslims. For them, God has reserved a hundred grades in paradise, and the distance between each of two grades is like the distance between the heaven and the earth (Bukhari, Jihaad, 4: 2790). Moreover, it is reported in the hadith sources that the Prophet of Islam stated that there is no deed that equals jihad (in reward) (Bukhari, Jihaad, 1: 2785), he described the best among people as "A believer who strives his utmost in Allah's Cause with his life and property" (Bukhari, Jihaad, 2: 2786), and said the best deed is "to believe in Allah and to fight for His cause" (Bukhari, Itk, 2: 2518).

However, if we leave aside the misunderstandings that are created by some codes inserted within the analyses of the Western orientalist approach, the belief of paradise in Islam cannot be explained with simplistic and debasing interpretations such as "limitless debauchery". It is true that Islam's vision of paradise is different in many aspects and more picturesque than the Judaic vision which offers a resurrection and domination on earth, and mentioned indistinctly, or than its counterpart in Christian theology that is much more modest and more toward the otherworld, toward the satisfaction of spirituality when compared in details. Islam's vision of paradise is a different depiction that goes far beyond being simply a secret garden where the goods are rewarded. However, what this depiction means for a radical who still lives on earth - as well as for every "regular" Muslim who have to be mentioned as "moderate" because of the presence of radicals - cannot be understood with a long discussion of maidens waiting in pavilions, rivers and lofty dwellings that often referred to in picturesque narratives.

Within the established economic system, Islam's vision of paradise has now gained a new and political meaning; it has been much easier to read it as a quite radical criticism of the current unequal distribution of values in the world. If Islam were not a religion, only the genuineness of this image of paradise (the truthfulness of its ideal) could have raised millions of followers again as an ideology that has very strong motivational tools which would make it possible transform the world. Today, three essential features of the vision of paradise stand out for a radical Salafi Muslim who lives in the Middle East.

\subsubsection{Strong References to an Egalitarian Worldly Welfare}

A literal understanding of the words of the description of paradise in Quran, which is elaborated in detail, shows that it actually consists of heavenly references to a worldly welfare. In Islamic imagination, prosperity - in the actual sense on earth - is distributed to anyone who enters paradise and its welfare is made experienced by all those who are in paradise. The first thing that stands out are private houses that resemble pavilions. High and safe houses, with streams flowing underneath, are mentioned in many verses of Quran (Quran 34:37, 29:58).

The houses in paradise are large estates with gardens (Gümüşhanevi, 2013:113/8) and are safe places surrounded with walls (Ramuz el-Ehadis-1, p. 125/5). Moreover, it is reported that there are big bazaars in paradise which we can compare with shopping malls today. It is expressed that there will be lots of provisions in these bazaars which will be visited even by angels, and these bazaars will be a place for meeting and chatting for the people of paradise (Imam Sharani, 1981:325-326/563; 326/564).

In this respect, every Muslim who fulfills the commands of God on earth will be rewarded with full and equal "economic welfare" in the afterworld. The most fundamental theme of reward is about meeting the need of shelter, which is recounted with mentioning private houses in gardens at the cities with large bazaars.

\subsubsection{A Free Environment Where the Worldly Prohibitions are Lifted}

Islamic faith prohibits the consumption of certain foods such as pork as well as all alcoholic beverages, introduces some restrictions to man-woman relationships. Yet all these restrictions are lifted in paradise. For instance, one verse of Quran mentions of rivers of wine among those blessings that will be offered to those who enter paradise (Quran 47:15). Similarly, the vision of paradise in Quran is a place where unburdened relationships will be experienced with women that are described as maidens [houri]. According to the descriptions in Quran, those in paradise are happily occupied (Quran 36:55) and all that pleases the eyes will be there (Quran 43:71). Thus, there is no sin left to condemn, no prohibition or forbidden thing or deed that could lead to intolerance or cause people to discomfort each other.

\subsubsection{An Image of God which is not Incompatible with All These}

The most important difference that is brought to us on the topic of paradise in Islamic theology is that the image of paradise turns upside down many teachings about this world. The prohibitions in this world are lifted in paradise, the 
servitude to rules ends up with absolute freedom in paradise. It is of course possible for a person to be free about his/her self [nafs]. For instance, a person can consume alcohol, can prefer not to lead a monogamous life. Yet, this creates an inconsistency with his/her faith in God. This perception is reversed in paradise: now God is present harmoniously together with all (reversed) prohibitions. Hence, paradise is actually a place where the inconsistency between faith in God and human pleasures disappears and they can coexist acknowledging each other.

Following this new reading that is based on these three aspects, it will be seen that the Islamic imagination of paradise resembles "the American Dream". The American Dream is, in summary, a tradition of thinking in the US that supports, with various images, the possibility of success and welfare for everyone through hard work. The most famous definition of the American Dream, which finds a place in numerous places, from Hollywood movies to computer games, is provided by James Truslow Adams in his book The Epic of America, published in 1931:

\begin{abstract}
...that dream of a land in which life should be better and richer and fuller for everyone, with opportunity for each according to ability or achievement. It is a difficult dream for the European upper classes to interpret adequately, and too many of us ourselves have grown weary and mistrustful of it. It is not a dream of motor cars and high wages merely, but a dream of social order in which each man and each woman shall be able to attain to the fullest stature of which they are innately capable, and be recognized by others for what they are, regardless of the fortuitous circumstances of birth or position.
\end{abstract}

In this text, the American Dream is defined as a dream of a land where life is better, richer, and fuller for everyone. It is elaborated as a dream of a social order in which each man and woman are able to attain to the fullest their innate capacities and are recognized by others for what they are. Similarly, the United States Declaration of Independence, adopted on July 4, 1776, declares that "life, liberty and the pursuit of happiness" are unalienable rights of men endowed by God and of course the American Dream is born out of these rights.

This shining dream transmits itself through some symbols such as multi-floor houses with gardens, happy people, large dining tables through the means of Hollywood movies. The idea of a land that is richer and fuller for everyone reminds of paradise, the secret garden, of Islam. The connotations of this dream, which is based on things a regular employee would acquire in the US, for a Salafi living under an anti-democratic oppressive regime in the Middle East can only pertain to paradise. The similarity is remarkable for a radical who obtains his information about the US from TV, movies, Internet and video games, even though s/he may have never visited the country; in this country, people are living happily in comfortable, lofty dwellings with gardens. Alcohol and pork consumption is free in this country, as seen for instance in Christmas scenes in movies, and moreover, a sexual liberty that is not seen in most of the Eastern cultures is tolerated by the society. Furthermore, it is perceived as completely normal that families in Hollywood movies go to church and celebrate religious holidays as part of their culture, and the president of this country is quoting bible in his address to his citizens. In other words, there is a God that can be present without creating a disharmony midst all this liberty. Thus, we can see that for a radical Muslim, the American Dream is a heavenly reflection of paradise with all its strange similarities.

This paradise on earth is a place for which a Muslim prays five times a day, fasts throughout the years, participates in jihad and risks death for the afterlife. Moreover, this place presents the life of a Salafi's paradise now as a Christian country for those who are, according to his/her faith, on the wrong path, and despite the fact they haven't done anything for it. One of the things that render the American Dream a religious image more than a real country on earth is that it is very difficult to attain for some people and remains far away truly like a dream. Just like the true path in Islam - bearing the qualities of being a Muslim - is a grace that is endowed by Allah and is expected to be endorsed on earth, similarly being an American citizen can only be attained by the approval of the United States of America. Without this, one cannot attain the return even though that person can have the potential to do everything that is required. In other words, being a human is not enough to live this dream. This welfare have to be "granted" as it is in religious doctrine. There is no return for someone who is not American - for instance, a Middle Eastern - even if s/he is hardworking; his/her ideal state is preserved in what already belongs to him. In this way, the American Dream is not free entry for everyone even though it is announced to everyone, an encouraged dream that is yet hard to reach. On the contrary, a Salafi can find an easy way to enter his own paradise.

\title{
5. Conclusion
}

What makes a Salafi living in the Middle East anti-American is not his fight against his "own temptation" but his ambition of turning the world, of those who have established his own paradise that he wants to enter - and the American Dream on earth, into hell. In other words, this Salafi sees these attacks as legitimate not because s/he does not trust 
himself/herself or his/her faith, or because of a sense of inferiority, but rather because s/he deems only himself/herself as worthy of entering paradise. This struggle is not a struggle of two political actors, but a conflict of two dreams, two images.

The greatest mistake one can do while dealing with ISIS and other Islamist terrorist groups that originated in the Middle East is to put them within the same wide group of "fundamentalists" together with Buddhist and Christian fundamentalists as well as with other Muslims. As a matter of fact, considering a Salafi group in the same circle with other Muslims would also lead to a mistaken approach. The simplifying logic of this generalizing approach would be so mistaken about its assessments on Salafi Islam that it can never be able to explain this tone of radicalism neither in its reasons nor outcomes. When we analyze the imaginations of a Buddhist or Christian radical about paradise we notice that these are not imaginations that have an intense counterpart in the world as that of Islam. Hence, they never see people who have already entered their own paradise in front of them. Inserting Salafi Islamist fundamentalism within a wide diagram in order to quickly analyze it amounts to re-reading it through the Western orientalist codes.

Just like one first needs to sleep in order to believe in the American Dream, in the words of the American comedian George Carlin, a radical has to die as s/he sees fit in order to reach the paradise of Quran. These words of Prophet Muhammad can be a reference for a Salafi who reads verses on jihad, when comparing the American Dream with the paradise of a radical: "Sleep is the brother of death" (Ibn Hanbel, 1983: 15.) Reading the fundamentalist Islamist movements with these references and values are necessary for a correct reading of communicative actions and discourses that emerge in this region of the world. An approach otherwise is bound to remain deficient.

\section{References}

Adams, J.T. (1931). The Epic of America. 2nd ed., Greenwood Press.

Al-Bukhari, Sahih. (Online) Available: http://www.sunnah.com/bukhari (March 20, 2015)

Bilmen, Ö. N. (1999). Hukuk-u Islamiye ve islahat-ı fıkhiyye kamusu (The public of Islamic law and reforms of figh). Istanbul: Öz Ensar Publication.

Çelik, E. E. (2013). Gadamer'in hermeneutik ufku ve Nıetzsche'nin perspektivizmi (Gadamer's hermeneutics and perspectivism of Nietzsche). Journal of FLSF, 15, 127-144.

El-Imam Ahmed Bin Hanbel. (1983) Ez-Zühd. Daru'l-Kütübi'l-IImiyye. Beyrut.

Gadamer, H. G. (2013). Truth and Method, New York: Bloomsbury Publishing.

Gümüşhanevi, A. Ziyaüddin. (2013). Ramuz el-Hadis-1. Istnbul: Pamuk Publishing.

Gürhan, N. (2011). Kadın Bakış Açısıla Kuran'ı Yeniden Okuma Denemesi (Re-read the Quran from women's perspective). Journal of e-Şarkiyat IImi Araştırmalar, 6, 112-124.

Imam Sharani. (1981). At-Tadhkirah Al-Qurtubi. Bedir Press.

İşcan, M. Z. (2013) Selefiliğin Şiilik değerlendirmeleri bağlamında nefret ve şiddet söylemi (Hate and violence of Salafism in the context of Shi'ism). Journal of e-Makalat Mezhep Araştırmaları, 6:2, 151-172.

Meriç, C. (2013). Kültürden Irfana (From culture to aufklarung). Istanbul: İletişim Press.

Muslim, Sahih. (Online) Available: http://www.sunnah.com/muslim (March 20, 2015)

Özcan, Z. (2000). Teolojik Hermenötik (Theologic hermeneutic). Istanbul: Alfa Press.

Said, E. (2003). Orientalism. London: Penguin Books.

Sönmez, V. (2010). Düşüncesinin Tarihi Arka Planı ve Selefilik. Scientific Journal of Araşan Institute of Social Sciences, 9-10,169-185.

Spinoza, B. (1922). Theologisch-Politischer Traktat. 4. bs. Leipzig: Verlag von Felix Meiner.

Tirmidhi, Jami at. [Online] Available: http://www.sunnah.com/tirmidhi (March 20, 2015).

Yılmaz, M. S. (2014) İslami Düşünce Tarihinde Bir Anlama Biçimi Olarak Selefilik Üzerine Bir Deneme (An essay about salafism as an understanding format). Journal of Insan ve Toplum Bilimleri Araştırmaları, 3, 532-553.

Zizek, S. (2009). A Glance into the Archives of Islam. (Online) Available: http://www.lacan.com/zizantinomies.htm (March 20, 2015)

Žižek, S. (2014a). ISIS is a Disgrace to True Fundamentalism. The New York Times, September 3, 2014.

Žižek, S. (2014b). İslam Arşivleri (Archives of Islam). Trans. Sabri Gürses, Istanbul: Çeviribilim Press. 